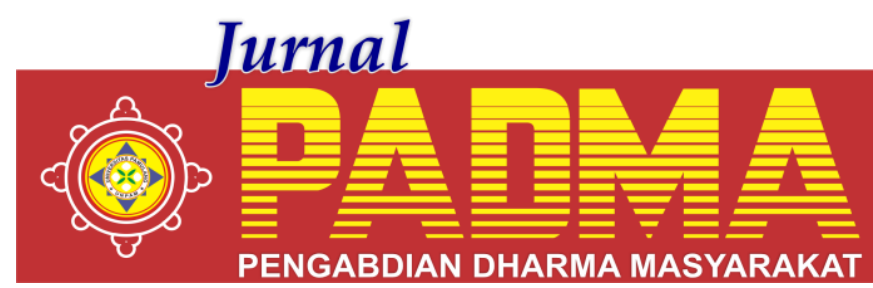

VOLUME 1, NOMOR 1, JANUARI 2021

\title{
PENYULUHAN WIRAUSAHA HOME INDUSTRI UNTUK MENINGKATKAN EKONOMI KELUARGA DENGAN DAUR ULANG BARANG BEKAS DI CIBODAS KECIL KARAWACI KOTA TANGERANG
}

\author{
${ }^{1 *}$ Junaedi, ${ }^{2}$ Nia Kurniasih, ${ }^{3}$ Rianto Aditama, ${ }^{4}$ Irfan Rizka Akbar, ${ }^{5}$ Dwi Mas Ayu, ${ }^{6}$ Nurul \\ Fadilah \\ Universitsa Pamulang, Tangerang Selatan, Banten, Indonesia \\ *dosen02341@unpam.ac.id
}

\begin{abstract}
Abstrak
Banyak nya sampah botol minuman yang di buang sembarangan oleh segelintir orang dijalanan merupakan masalah untuk kebersihan lingkungan belum dapat di atasi. Dengan pengabdian kepada masyarakat, mencoba mencari solusi bahwa sampah botol minuman tersebut dapat dimanfaatkan menjadi bahan yang bernilai ekonomis. Metode kegiatan pengabdian masyarakat ini menggunakan metode ceramah, demontrasi langsung dipraktekkan oleh peserta, serta tanya jawab. Pelatihan ini melibatkan dosen Fakultas Teknik Industri , mahasiswa Teknik Industri yang dilakukan di Desa Cibodas Kecil, Karawaci yang melibatkan ibu-ibu PKK dilingkungan sekitar. Target luaran program pengabdian ini adalah (1) masyarakat mulai mengetahui bahwa barang bekas bisa didaur ulang, (2) masyarakat memiliki pengetahuan dan kemampuan tentang teknik pengolahan sampah jenis botol bekas minuman menjadi barang yang memiliki nilai ekonomis, dan (3) terciptanya peran serta masyarakat secara aktif dalam memecahkan masalah sampah dengan memilah sampah an organik yang masih bisa mempunyai nilai ekonomis. Pelatihan membuat barang fungsional dari bahan botol plastik cukup berhasil sesuai dengan harapan, terlihat dari jumlah yang dihasilkan $80 \%$ produk dalam kategori baik, sehingga menumbuhkan jiwa wirausaha Ibu-ibu PKK dengan cara mengembangkan kreativitas dalam mengolah sampah an organik lainnya untuk dapat dijadikan barang yang bernilai ekonomis dan dapat dijual.
\end{abstract}

Kata Kunci: benda fungsional, botol bekas minuman, wirausaha

\section{Abstract}

The large number of drink bottles that are thrown away carelessly by a handful of people on the streets is a problem for environmental cleanliness that cannot be overcome. With the dedication to the community, trying to find a solution that the beverage bottle waste can be used as an economically valuable material. This community service activity method uses the lecture method, direct demonstrations practiced by the participants, and questions and answers. This training involved lecturers of the Faculty of Industrial Engineering, Industrial Engineering students, which was conducted in Cibodas Kecil Village, Karawaci which involved PKK women in the surrounding environment. The output targets of this service program are (1) the community begins to recognize that used goods can be recycled, (2) the community has the knowledge and skills in processing used beverage bottles into goods that have economic value, and (3) creating community participation actively solving the waste problem by sorting out inorganic waste which can still have economic value. The training on making functional items from plastic bottles was quite successful in accordance with expectations, as seen from the number produced 80\% of products in good categories, thus fostering an entrepreneurial spirit for PKK mothers by developing creativity in processing other inorganic waste to become valuable goods economical and can be sold.

Keywords: functional objects, used beverage bottles, entrepreneurship

\section{PENDAHULUAN}

Botol bekas minuman adalah bagian dari sampah yang banyak ditemui di sekitar mereka, di lingkungan keseharian mereka hampir semua jajanan dalam bentuk minuman dan hampir semua membeli minuman tersebut. Apa yang dapat kita lakukan?, salah satunya adalah mendaur ulang sampah tersebut menjadi barang yang lebih berguna. Apabila dapat memanfaatkan sampah botol plastik tersebut berarti turut mendukung program 4R-P, yaitu reduce (mengurangi), reuse (menggunakan kembali), recycle (mendaur ulang), replace (mengganti barang berpotensi sampah kearah bahan recycle), participation 
(pelibatan masyarakat), dan mengubah sampah botol plastik bekas minuman menjadi barang yang bernilai ekonomis adalah bagian dari prinsip recycle ( mendaur ulang). Sesuai yang dilakukan Amri (2008) dalam Amelia Zahra (2014) Pemanfaatan Sampah Plastik Menjadi Barang Bernilai Guna.

Di masa pembangunan sekarang nilai ekonomi semakin berperan, maka kerajinan dipandang sebagai aset yang menguntungkan untuk dikembangkan. Dengan kata lain, kerajinan dipandang memiliki potensi ekonomi dalam perdagangan dan dunia pariwisata. Oleh karena itu, kegiatan kerajinan ini digalakkan dan diharapkan mampu meningkatkan devisa negara, sekaligus dapat memperluas lapangan kerja dan dapat meningkatkan pendapatan serta kesejahteraan. Sesuai dengan pengabdian kepada masyarakat yang dilakukan oleh MD Angendari (2012) tentang mengadakan pelatihan membuat kreasi benda fungsional dari kain flanel untuk menumbuhkan jiwa wirausaha yang dilakukan di Sekolah Luar Biasa Negeri Bagian B Singaraja.

Berdasarkan latar belakang tersebut, kami dari Team Program Pengabdian Kepada Masyarakat (PKM) Universitas Pamulang (UNPAM) yang beranggotakan 3 orang dosen dan 2 orang mahasiswa terpanggil untuk ikut serta membantu memecahkan persoalan yang dihadapi oleh warga masyarakat pada umum nya dan khususnya untuk ibu PKK di Cibodas Kecil Tangerang PKM yang akan kami laksanakan berjudul " Penyuluhan Wirausaha Home Industri Untuk Meningkatkan Ekonomi Keluarga Dengan Daur ulang Barang Bekas"

Tujuan dari kegiatan PKM sebagai berikut, tujuan pertama adalah masyarakat mulai mengetahui bahwa barang bekas bisa didaur ulang, tujuan kedua adalah masyarakat memiliki pengetahuan dan kemampuan tentang teknik pengolahan sampah jenis botol bekas minuman menjadi barang yang memiliki nilai ekonomis, dan yang ketiga adalah terciptanya peran serta masyarakat secara aktif dalam memecahkan masalah sampah dengan memilah sampah an organik yang masih bisa mempunyai nilai ekonomis.
Target luaran yang dihasilkan adalah berupa pot bunga dari botol minuman, serta kegiatan ini dipublish di media masa dan juga jurnal nasional.

\section{METODE}

Sampah an organik bekas botol minuman dimanfaatkan menjadi bahan yang bernilai ekonomis. Barang yang akan dihasilkan adalah berupa barang souvenir seperti : celengan, pot bunga, dompet, tempat pinsil, tempat sampah dan lain-lain. Untuk kegiatan PKM kali ini akan membuat salah satu contoh daur ulang dari barang bekas botol minuman adalah pembuatan pot bunga.

Kegiatan pelatihan pembuatan kreasi benda fungsional dari botol minuman di Desa Cibodas Kecil, Karawaci dilaksanakan hari minggu tanggal 13Desember 2020.Kegiatan dimulai pukul 08.30 sampai dengan pukul 15.00.Kegiatan diawali dengan mengumpulkan peserta di aula posyandu yang sekaligus sebagai tempat pelatihan dan peserta ibu-ibu PKK sebanyak 10 orang.Pemberdayaan ibu-ibu PKK sebagai anggota masyarakat dan masih tergolong sebagai tenaga kerja produkstif sangat penting dilakukan, dalam kaitannya dengan upaya untuk membina dan mengembangkan porsi keluarga dan daerah, dapat dilakukan melalui berbagai alternatif kegiatan, diantaranya berupa pelatihan pembuatan daur ulang brang bekas dari botol minuman. Alternatif ini dipilih mengingat ibu-ibu PKK diwilayah ini sangat membutuhkan pengetahuan dan keterampilan yang dapat dijadikan bekal untuk merintis peluang usaha.

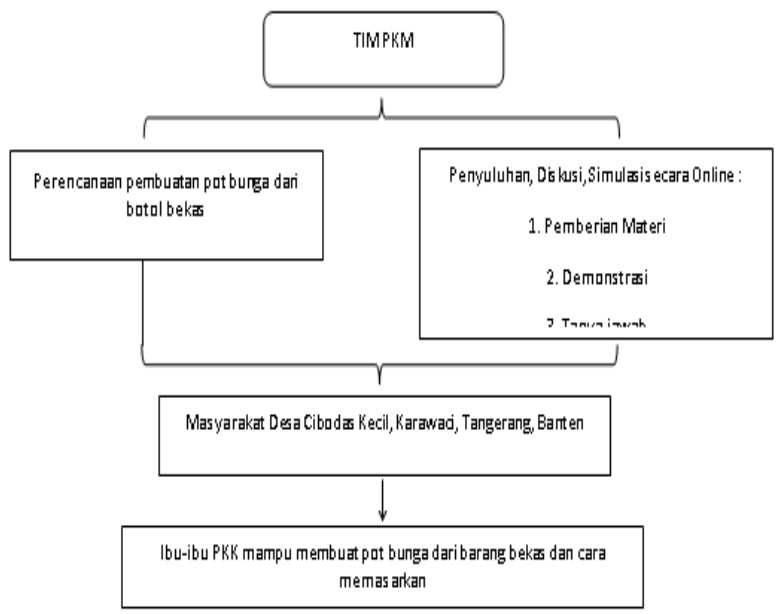

Gambar 1. Kerangka Pemecahan Masalah 
Kegiatan pengabdian ini dilakukan di Desa Cibodas Kecil, Karawaci dengan Ibu-Ibu PKK RT 01 RW 03. Kegiatan yang akan dilakukan adalah sebagai berikut:
1. Kordinasi degan pihak-pihak terkait.

2. Persiapan penyuluhan dan pelatihan

3. Rincian acara

Tabel 1

Rincian Acara Pelaksanaan Kegiatan

\begin{tabular}{|c|c|c|c|}
\hline Hari/ Tanggal & Waktu & Susunan Acara & Penanggung Jawab \\
\hline \multirow{11}{*}{$\begin{array}{l}\text { Minggu, } 13 \text { Desember } \\
2020\end{array}$} & $08.30-08.40$ & Pembukaan & $\mathrm{MC}$ \\
\hline & $08.40-09.00$ & Sambutan Ketua Pelaksana & Junaedi S.T., M.M \\
\hline & $09.00-09.20$ & Sambutan Ketua RT/Ibu PKK & Teti Sumiati \\
\hline & $09.20-10.30$ & Penyampaian Materi & Nia Kurniasih S.T., M.M \\
\hline & $10.30-12.00$ & Praktek pembuatan pot bunga & Rianto Aditama S.T., M.M \\
\hline & \multirow{3}{*}{$13.00-14.30$} & \multirow{3}{*}{ Tanya Jawab } & $\mathrm{MC}$ \\
\hline & & & Peserta \\
\hline & & & Narasumber \\
\hline & \multirow{2}{*}{$14.30-15.00$} & Kesimpulan & \multirow{2}{*}{ Perwakilan Panitia } \\
\hline & & Penutup & \\
\hline & 15.00 & Acara Selesai & $\mathrm{MC}$ \\
\hline
\end{tabular}

\section{HASIL DAN PEMBAHASAN}

Pelaksanaan kegiatan yang akan dilakukan untuk mengatasi permasalahan adalah sebagai berikut (Silvia \& Permana, 2018):

1. Penyuluhan

Materi penyuluhan adalah pelatihan pembuatan pot bunga dari botol minuman. Tujuan: penyuluhan ini adalah memberikan ilmu dan wawasan baru kepada ibu-ibu PKK tentang wirausaha dan peluang usaha rumahan, sehingga terbuka pikiran serta tumbuh minat dan motivasi dalam diri mereka untuk berwirausaha. Disamping itu juga diberikan materi tentang prinsip dasar pembuatan, bertujuan agar mitra mengetahui cara pembuatan. Penyuluhan ini disampaikan dalam bentuk ceramah dan tanya jawab kepada peserta

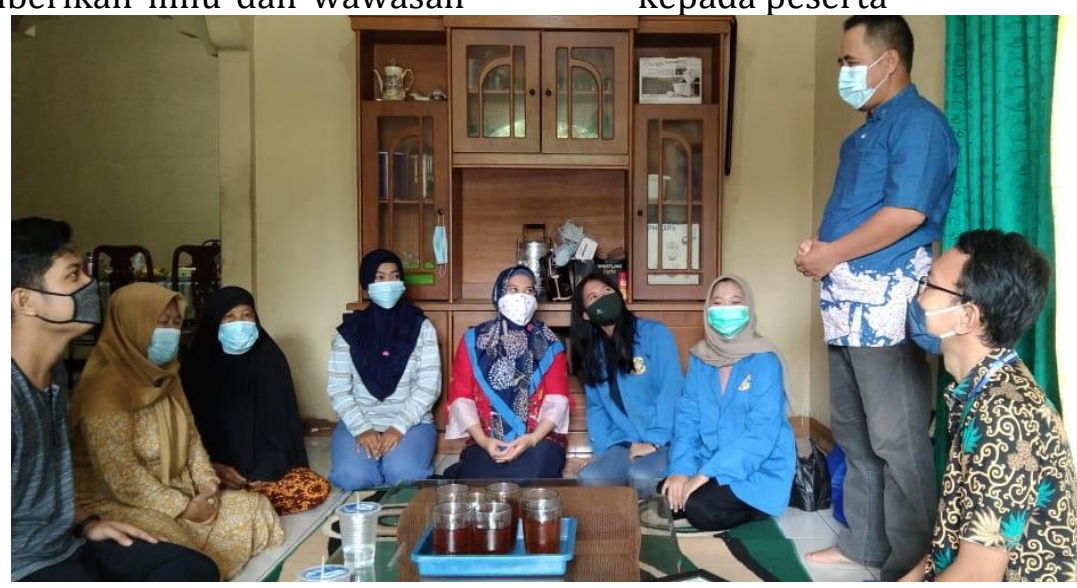

Sumber: Dokumentasi kegiatan PKM, Desember 2020

Gambar 2. Pembukaan Penyuluhan Wirausaha Home Industri Pot Bunga

2. Pelatihan

Materi pelatihan adalah cara pembuatan pot bunga dari botol minuman. Kegiatan ini bertujuan untuk memberikan keterampilan tentang cara pembuatan pot bunga dari botol minuman. Pelatihan tersebut disampaikan dalam bentuk ceramah yang dilanjutkan dengan eksperimen langsung dan tanya jawab tentang cara pembuatan produk tersebut. Pelatihan dilaksanakan sampai semua peserta mahir mempraktekkan sendiri

3. Prosedur kegiatan

Kegiatan pengabdian ini meliputi: 1) Koordinasi dengan mitra, terkait dengan penyusunan jadwal kegiatan; 2) Persiapan penyuluhan dan pelatihan; 3) Penyuluhan tentang prinsip dasar pembuatan pot bunga dari botol plastik; 4) Pelatihan cara pembuatan pot bunga 
dari botol plastik; dan 5) Pembinaan pasca kegiatan.

4. Partisipasi Mitra

Partisipasi mitra dalam pelaksanaan kegiatan ini adalah partisipasi aktif, dari mulai perencanaan kegiatan, penyusunan jadwal penyuluhan dan pelatihan. Partisipasi mitra akan dievaluasi. Evaluasi akan dilaksanakan selama dan setelah pelaksanaan kegiatan penyuluhan dan pelatihan. Selama pelaksanaan kegiatan dilakukan evaluasi dengan metode pengamatan langsung oleh Tim Pengabdian.

Sedangkan setelah pelaksanaan kegiatan dilakukan evaluasi dengan metode pengamatan terhadap hasil kegiatan. Kriteria evaluasi meliputi kasadaran dan antusiasme peserta penyuluhan dan pelatihan dalam mengikuti kegiatan serta tingkat kemahiran peserta dalam mempraktekkan sendiri pembuatan pot bunga dari botol plastik yang telah diajarkan.

Kegiatan pengabdian ini dilakukan di Desa Cibodas Kecil, Karawaci, dengan IbuIbu PKK RT 01 RW 03. Kegiatan yang dilakukan adalah sebagai berikut:

1. Koordinasi dengan pihak-pihak yang terkait

Koordinasi tim pengabdian kepada masyarakat Program Studi Teknik Industri dilakukan dengan mitra yaitu Ketua PKK RT 01 RW 03 Desa Cibodas Kecil, Karawaci. Pada kegiatan ini tim pengabdian dan mitra membahas tentang kegiatan pengabdian kepada masyarakat yang akan dilaksanakan, tempat dan waktu pelaksanaan penyuluhan dan pelatihan. Pada pertemuan ini ada beberapa hal yang disepakati, yaitu kegiatan pengabdian kepada masyarakat, waktu dan tempat pelaksanaan penyuluhan pelatihan pembuatan pot bunga dengan botol plastik.

2. Persiapan penyuluhan dan pelatihan

Persiapan kegiatan ini berupa penentuan formula pot bunga dengan botol plastik, pembuatan modul penyuluhan dan pelatihan. Modul pelatihan berisi tentang bahan-bahan, alat-alat dan cara pembuatan pot bunga dengan botl plastik. Pada persiapan pelatihan, Tim pengabdian kepada masyarakat melakukan uji coba resep pembuatan pot bunga dengan botol plastik, sehingga didapatkan komposisi yang tepat dan memberikan hasil optimal.

3. Bahan Baku Pembuatan Pot Bunga

Tabel 2

Bahan Baku

\begin{tabular}{|c|c|c|c|}
\hline Bahan & Fungsi & Kuantitas & Satuan \\
\hline $\begin{array}{c}\text { Botol } \\
\text { plastik }\end{array}$ & $\begin{array}{c}\text { Bahan utama } \\
\text { pot bunga }\end{array}$ & 15 & Pcs \\
\hline $\begin{array}{c}\text { Guntin } \\
\text { g }\end{array}$ & $\begin{array}{c}\text { Memotong } \\
\text { botol plastik }\end{array}$ & 15 & Pcs \\
\hline Spidol & $\begin{array}{c}\text { Menulis } \\
\text { ukiran pot }\end{array}$ & 15 & Pcs \\
\hline $\begin{array}{c}\text { Pengga } \\
\text { ris }\end{array}$ & $\begin{array}{c}\text { Meluruskan } \\
\text { ukiran pot }\end{array}$ & 15 & Pcs \\
\hline $\begin{array}{c}\text { Cutter } \\
\text { pisau }\end{array}$ & $\begin{array}{c}\text { Untuk } \\
\text { diawal }\end{array}$ & 15 & Pcs \\
\hline Baut & $\begin{array}{c}\text { Pengencang } \\
\text { pot bunga }\end{array}$ & 20 & Pcs \\
\hline Pilok & $\begin{array}{c}\text { Mewarnai } \\
\text { botol plastik }\end{array}$ & 15 & Pcs \\
\hline
\end{tabular}

4. Proses Pembuatan Pot Bunga dari Botol Plastik. Pembuatan pot bunga dengan tahapanyang benar akan menghasilkan pot bunga yang berkualitas. Berikut susunan pembuatannya :

a. Siapkan masing-masing 1 buah botol plastik, minimal ukuran $600 \mathrm{ml}$,

b. Lepas label kemasan botol plastik jika masih ada,

c. Siapkan spidol dan penggaris untuk mengukur jarak yang akan digaris,

d. Garis ukuran dengan spidol dan penggaris, ukur sesuai keinginan, minimal jarak ukuran $1 \mathrm{~cm}$,

e. Jika sudah siapkan cutter/pisau untuk memotong botol di awal,

f. Lalu gunting botol plastik yang sudah di ukur,

g. Putar balik botol yang sudah digunting keseluruhan,

h. Jika ingin diwarnai, silahkan di pilok terlebih dahulu,

i. Jika sudah dipilok, kencangkan botol tersebut dengan sebuah baut. 


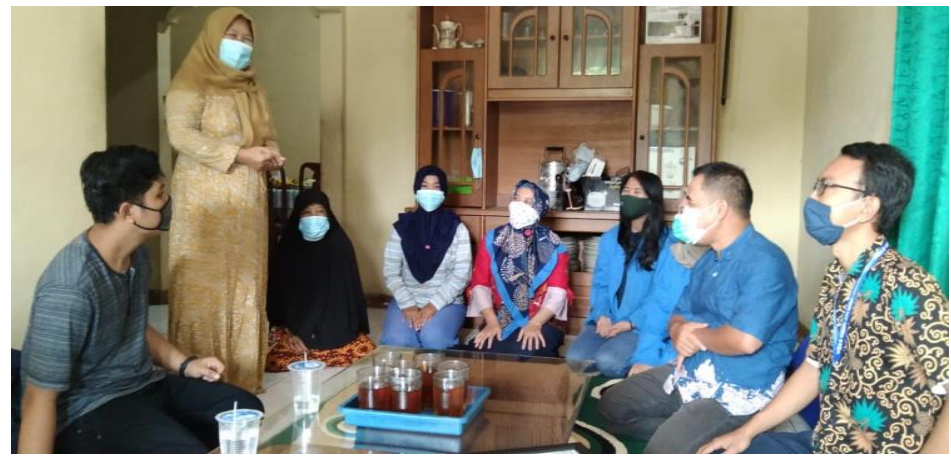

Gambar 3. Sambutan Ibu RT Tentang Wirausaha Home Industri

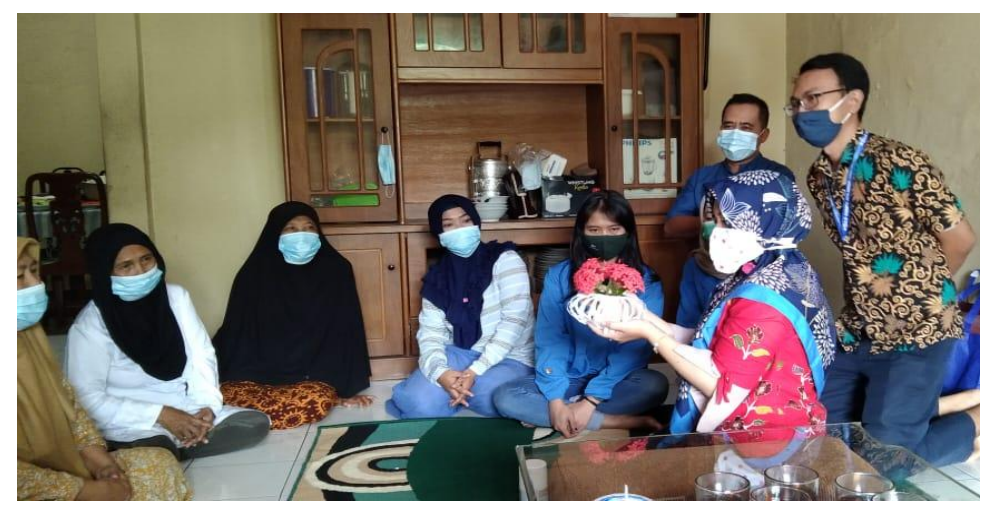

Gambar 4. Pemberian Materi dari Keterampilan Botol Bekas Menjadi Pot Bunga

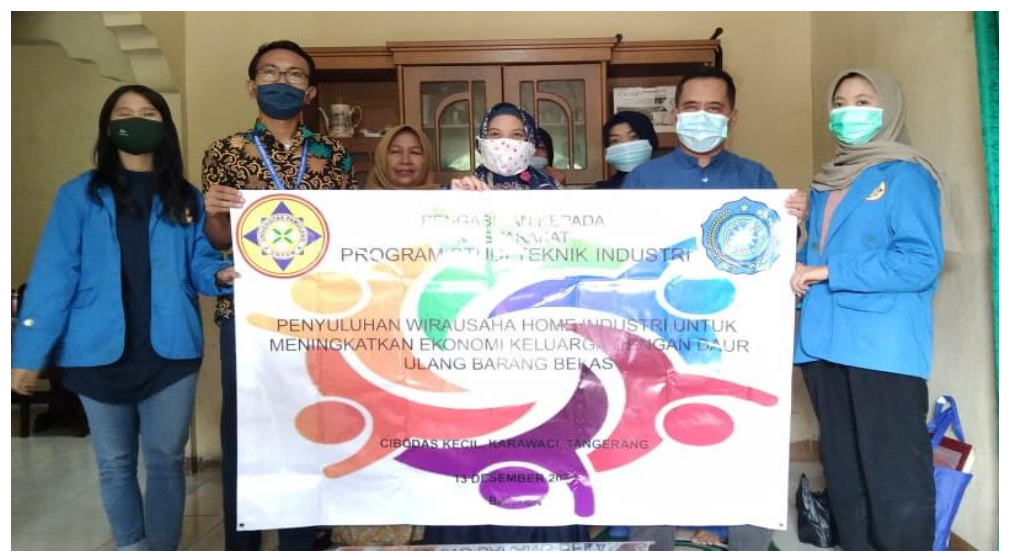

Gambar 5. Pelaksanaan PKM Keterampilan Wirausaha Home Industri

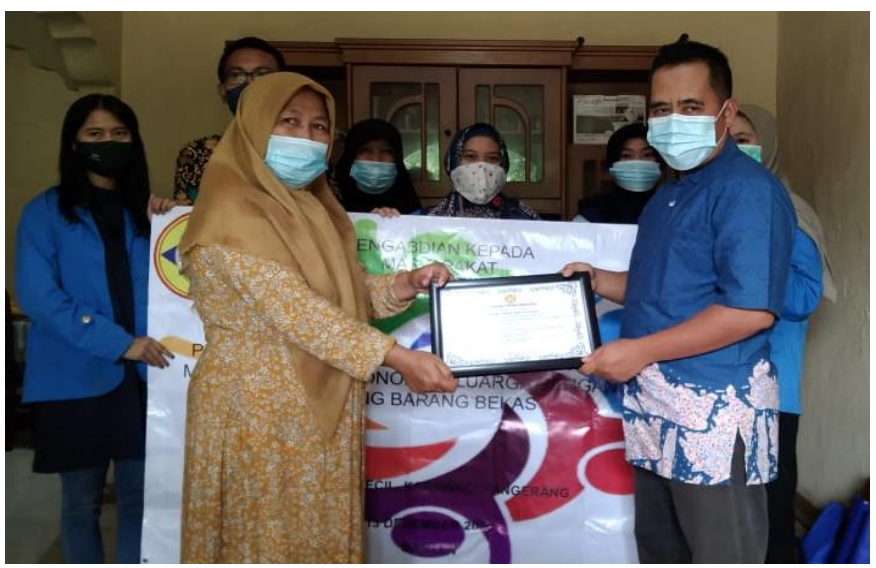

Gambar 6. Pemberian Piagam PKM Keterampilan Wirausaha Home Industri 


\section{PENUTUP}

\section{Simpulan}

Dalam pelatihan pembuatan pot bunga dengan botol plastik dapat diambil kesimpulan bahwa kegiatan dapat berjalan dengan lancar sesuai dengan yang direncanakan.Kegiatan ini dapat meningkatkan pengetahuan dan keterampilan dalam pembuatan pot bunga dengan botol plastik yang dapat digunakan pribadi maupun dijadikan usaha sehari-hari.

\section{Saran}

Saran dari pengabdian kepada masyarakat ini harapannya kegiatan ini berkesinambungan bukan hanya sebagai pengetahuan saja tetapi dapat di terapkan sehari-hari.

\section{DAFTAR PUSTAKA}

Akbar, I. R., Prasetiyani, D., \& Nariah, N. (2020). Pengaruh Motivasi Terhadap Kinerja Karyawan Pada Pt. Unggul Abadi Di Jakarta. Jurnal Ekonomi Efektif, 3(1).

Amri (2008.) Sulap sampah Jadi Barang Bermanfaat

Angendari MD (2012) Pelatihan Membuat Kreasi Benda Fungsional dari Kain Flanel untuk Menumbuhkan Jiwa Wirausaha di Sekolah Luar Biasa Negeri Bagian B Singaraja.https://ejournal.undiksha.ac. id/index.php/JPKM/article/view/927 $\underline{8}$
Effendy, A. A., Sunarsi, D., Kristianti, L. S., Irawati, L., \& Wahyitno, W. (2020). Effect Of Giving Reward and Motivation to Employee Productivity In PT. Sinar Kencana Jaya In Surabaya. HUMANIS (Humanities, Management and Science Proceedings), 1(1).

Gunartin, G., Mulyanto, E., \& Sunarsi, D. (2020). The Role Analysis of Waste Bank in Improving the Community's Creative Economy (Study at Ketumbar Pamulang Waste Bank). Budapest International Research and Critics Institute (BIRCI-Journal): Humanities and Social Sciences, 3(4), 3262-3269.

Husniati Renny (2018), Pelatihan membuat kreasi benda fungsional dari botol bekas minuman untuk menumbuhkan jiwa wirausaha di rumah yatim asholihin.

Maddinsyah, A., Hidayat, D., Juhaeri, J., Susanto, D., \& Sunarsi, D. (2020). Desain Formulasi Dan Implementasi Bisnis Strategik Dengan Pendekatan Business Model Canvas (BMC) Terintegrasi Kerangka Integrated Performance Management System (IPMS) Pada Koperasi Asperindo. Inovasi, 7(2), 67-76.

Zahra Amelia (2014), Pemanfaatan Sampah Plastik Menjadi Barang Bernilai Guna ameliaazzahra5.blogspot.com/2014/0 $1 /$ karya-tulis-ilmiah-tentangpemanfaatan.html 